\title{
Longhorned woodboring beetles (Coleoptera, Cerambycidae) from Cusuco National Park, Honduras: new species, new records, and revalidation
}

\author{
Antonio SANTOS-SILVA ${ }^{\circledR 1}$, Martijn VAN ROIE ${ }^{\circledR 2, *} \&$ Merlijn JOCQUÉ ${ }^{3}$ \\ ${ }^{1}$ Museu de Zoologia, Universidade de São Paulo, São Paulo, SP, Brazil. \\ ${ }^{2,3}$ Biodiversity Inventory for Conservation npo (BINCO), \\ Walmersumstraat 44, 3380 Glabbeek, Belgium. \\ ${ }^{2}$ Department of Biology, Ecosystem Management Research Group, University of Antwerp, \\ Universiteitsplein 1, 2610 Wilrijk, Belgium. \\ ${ }^{3}$ Operation Wallacea, Wallace House, Old Bolingbroke, Lincolnshire, PE23 4EX, UK. \\ ${ }^{3}$ Aquatic and Terrestrial Ecology (ATECO), Royal Belgian Institute of Natural Sciences (RBINS), \\ Vautierstraat 29, 1000 Brussels, Belgium. \\ *Corresponding author: martijn.vanroie@binco.eu \\ 1Email: toncriss@uol.com.br \\ ${ }^{3}$ Email: merlijn.jocque@binco.eu \\ ${ }^{1}$ urn:1sid:zoobank.org:author:147209A1-FA0E-4AE3-8F10-A5CADAB6EE98
${ }^{2}$ urn:1sid:zoobank.org:author:BC5F187A-EF47-45E5-9218-91B1CB41397D
${ }^{3}$ urn:1sid:zoobank.org:author:6F4C1B5C-BDD9-4217-8F29-95ADA5E9F4D3
}

\begin{abstract}
An ongoing study of the longhorned beetle fauna in the cloud forests of Cusuco National Park revealed multiple additions to the Honduran fauna. Four new species are described: Heterachthes caceresae sp. nov. (Cerambycinae, Neoibidionini), Oreodera kawasae sp. nov. (Lamiinae, Acrocinini), Phrynidius guifarroi sp. nov. (Lamiinae, Apomecynini), and Strangalia lunai sp. nov. (Lepturinae, Lepturini). Additionally, Lagocheirus parvulus Casey, 1913 (Lamiinae, Acanthocinini) is revalidated as Lagocheirus araneiformis parvulus Casey, 1913 (Lagochirus [sic]). We recorded Arixiuna varians (Bates, 1881) (Lamiinae, Hemilophini) for the first time for Honduras. These findings confirm how poorly the invertebrate biodiversity of cloud forests is documented and hints at the large number of species we are losing with the ongoing deforestation.
\end{abstract}

Keywords. Central America, Neotropical Region, taxonomy, Phytophaga, conservation.

Santos-Silva A., Van Roie M. \& Jocqué M. 2021. Longhorned woodboring beetles (Coleoptera, Cerambycidae) from Cusuco National Park, Honduras: new species, new records, and revalidation. European Journal of Taxonomy 764: 37-61. https://doi.org/10.5852/ejt.2021.764.1469 


\section{Introduction}

Mesoamerica is one of the world's biodiversity hotspots (Myers et al.2000) and particularly rich in montane forests frequently covered in clouds or mist. These cloud forests are centers of endemism for a wide range of organisms (Jones et al. 2008) including invertebrates (Anderson \& Ashe 2000). A series of protected areas were installed across Honduras following the Government's Cloud Forest Act (Act 87-1987) to protect the watersheds that provide drinking water for the large cities. Despite the vital importance of cloud forests for biodiversity conservation and ecosystem services (Pope et al. 2015), these ecosystems are highly threatened. Deforestation and habitat destruction are global problems, but Honduras possesses one of the highest relative deforestation rates of any Central American country (Magrin et al. 2014), and one of the worst rates globally for deforestation in protected areas (Hansen et al. 2020). Particularly worrisome is the hostile environment for activists protecting forests and rivers (e.g., Global Witness 2017).

The information available on cloud forest biodiversity remains scattered and particularly the invertebrate fauna is little known (Bruijnzeel \& Veneklaas 1998). Possibly one of the better studied cloud forests in Honduras with regards to its biodiversity is Cusuco National Park (CNP) (Martin et al. 2021), situated in the Merendón mountain range, close to Guatemala. CNP is recognized as a site of critical importance for the conservation of amphibians, birds, and mammals (Le Saout et al. 2013). Also here a large part of the invertebrate biodiversity remains unstudied and unknown. Yearly repeated light trapping surveys resulted in the discovery of a large charismatic longhorn Derobrachus cusucoensis Santos-Silva, Mal, Van Roie \& Jocqué, 2018 (Coleoptera, Cerambycidae) (Santos-Silva et al. 2018). Since then, a more thorough investigation of the longhorned woodboring beetle fauna of CNP has been initiated, of which some results are reported in this work.

We here describe four new species of Cerambycidae from the cloud forests in CNP. The new species were named after Honduran environmental activists in honor of their dedication to protect biodiversity and nature. We further record a new addition to the Honduran longhorn fauna, and provide arguments for the revalidation of Lagocheirus parvulus Casey, 1913 as Lagocheirus araneiformis parvulus.

\section{Material and methods}

Photographs were taken in the MZSP with a Canon EOS Rebel T3i DSLR camera, Canon MP-E $65 \mathrm{~mm} \mathrm{f} / 2.8$ 1-5X macro lens, controlled by Zerene Stacker AutoMontage software. Measurements were taken in mm using measuring ocular Hensoldt/Wetzlar-Mess 10 in the Leica MZ6 stereo microscope, also used in the study of the specimens.

The acronyms used in the text are as follows:

ACMT $=$ American Coleoptera Museum (James Wappes), San Antonio, Texas, USA

$\mathrm{CBG}=$ Centre for Biodiversity Genomics, University of Guelph, Guelph, Canada

$\mathrm{CNP}=$ Cusuco National Park, Honduras

FSCA = Florida State Collection of Arthropods, Gainesville, Florida, USA

MZSP = Museu de Zoologia, Universidade de São Paulo, São Paulo, Brazil

RBINS $=$ Royal Belgian Institute of Natural Sciences, Brussels, Belgium 


\title{
Results
}

\author{
Class Insecta Linnaeus, 1758 \\ Order Coleoptera Linnaeus, 1758 \\ Suborder Polyphaga Emery, 1886 \\ Superfamily Chrysomeloidea Latreille, 1802 \\ Subfamily Cerambycinae Latreille, 1802 \\ Tribe Neoibidionini Monné, 2012 \\ Subtribe Compsina Martins \& Galileo, 2007 \\ Genus Heterachthes Newman, 1840 \\ Heterachthes caceresae sp. nov. \\ urn:1sid:zoobank.org:act:BED20ABD-5CD7-4C08-A1B3-A729208E0830
}

Figs $1-6$

\section{Diagnosis}

Heterachthes caceresae sp. nov. (Figs 1-6) is similar to H. viticulus Martins, 1970 (Figs 7-10), but differs as follows: antennae dark brown; distance between antennal tubercles less than half of basal width of scape; prothorax in male proportionally longer (Fig. 1); pronotum not transversely rugose (Fig. 5). In $H$. viticulus, antennae are reddish, distance between antennal tubercles distinctly greater than half of basal width of scape, prothorax in male proportionally shorter (Fig. 10), and pronotum is distinctly transversely rugose in both sexes (Figs 7-9).

\section{Etymology}

This species is named after Berta Isabel Cáceres Flores (Berta Cáceres for short) who supported indigenous communities and was an active opponent of illegal logging and mass plantations. She was murdered at her home in March 2016.

\section{Type material}

\section{Holotype}

HONDURAS • đ; Cortés, Cusuco National Park (Base Camp); 20 Jun. 2015; local collector leg.; light trap; RBINS 34.248.

\section{Paratype}

HONDURAS • ○`; Cortés, Cusuco National Park (Guanales); 13 Aug. 2015; local collector leg.; MZSP.

Measurements in mm (male holotype/male paratype)

Total length, 14.05/9.85; prothoracic length, 2.95/2.10; anterior prothoracic width, 1.80/1.25; posterior prothoracic width, 1.90/1.35; humeral width, 2.80/1.90; elytral length, 9.00/6.55.

\section{Description}

Male holotype (Figs 1-5)

Coloration. Integument mostly dark brown, dark reddish-brown on some areas; apex of palpomeres yellowish-brown; elytra with two longitudinal light maculae dorsally, one yellowish-brown on anterior half, another pale yellow on posterior half.

HEAD. Central plate of frons well-delimited, large transversely rugose-punctate; remaining surface of frons finely, sparsely punctate laterally, slightly rugose toward antennal tubercles; with a few short yellowish-white setae, including on posterior area of central plate. Vertex finely, shallowly, sparsely punctate, except area close to prothorax densely micropunctate, with fine punctures interspersed; area 
between antennal tubercles and upper eye lobes flattened; with a few long, erect yellowish-brown setae near posterior margin of upper eye lobes. Area behind eyes coarsely, somewhat rugose-punctate close to eye, shallowly, partially confluently punctate close to prothorax on area behind upper eye lobe, transversely striate-punctate close to prothorax on area behind lower eye lobe; with long, erect yellowish-brown setae close to eye, more abundant behind lower eye lobe, glabrous close to prothorax. Genae finely, partially confluently punctate, except smooth apex; with short, sparse yellowish-brown setae, except glabrous apex. Antennal tubercles moderately elevated, with rounded apex; finely, sparsely punctate, with a few short yellowish-white setae. Median groove distinct from clypeus to area between upper eye lobes. Gulamentum smooth, glabrous on posterior half, transversely striate-punctate, with short, sparse yellowish-brown setae, and long, erect setae of same color interspersed on anterior half. Distance between upper eye lobes 0.43 times length of scape, 0.29 times distance between outer margins of eyes; in frontal view, distance between lower eye lobes 0.63 times length of scape, 0.43 times distance between outer margins of eyes. Antennae 2.4 times elytral length, reaching elytral apex at apex of antennomere VII. Left antenna distinctly 12-segmented; antennomere XI of right antenna with division into a twelfth segment slightly marked. Scape gradually widened toward apex, finely, somewhat abundantly punctate basally, punctures sparser toward apex; with short, sparse yellowish setae, and long, erect setae of same color interspersed (erect setae more abundant ventrally). Pedicel with a few short, yellowish setae dorsally, and a few long, erect setae of same color ventrally. Antennomeres with abundantly yellowish-white pubescence not obscuring integument; antennomeres III-VI with long, erect yellowish setae ventrally, setae gradually sparser toward VI; antennomeres III-X with long, erect yellowish setae apically. Antennal formula based on length of antennomere III: scape $=0.57$; pedicel $=$ $0.11 ; \mathrm{IV}=0.74 ; \mathrm{V}=0.90 ; \mathrm{VI}=0.90 ; \mathrm{VII}=0.78 ; \mathrm{VIII}=0.77 ; \mathrm{IX}=0.77 ; \mathrm{X}=0.74 ; \mathrm{XI}=1.01$ (left antenna: $\mathrm{XI}=0.65 ; \mathrm{XII}=0.36$ ).

THORAX. Prothorax distinctly longer than wide; anterior constriction slightly marked; posterior constriction well-marked; nearly parallel-sided between constrictions. Pronotum with five slightly distinct gibbosities, one on each side of anterior third, one on each side of posterior third, another centrally, least distinct, on posterior half; somewhat finely, sparsely punctate; with long, erect, sparse yellowish-brown setae; with narrow grayish-white pubescent band close to posterior margin, more distinct laterally. Sides of prothorax with a few fine punctures on posterior $3 / 4$, transversely striate on anterior quarter; with a few long, erect yellowish-brown setae superiorly; area close to prosternum with dense golden pubescent band (yellower depending on light intensity) from apex of anterior quarter to near procoxal cavity (widened in this latter area), extended to posterior margin on right side. Prosternum smooth, with a few long, erect yellowish-brown setae on posterior half, transversely striate, with a few, both short and long yellowish-brown setae on anterior half. Prosternal process strongly narrowed centrally, glabrous. Mesoventrite with a few short yellowish-brown setae. Mesanepisternum with dense, golden pubescent band superiorly, glabrous on area close to mesoventrite; mesepimeron with abundant yellowish-brown pubescence not obscuring integument. Mesoventral process distinctly flap-shaped on sides of apex, apex centrally emarginate. Metanepisternum with dense golden pubescence. Sides of metaventrite with dense golden pubescence close to metanepisternum (widened posteriorly); remaining surface with long, erect, sparse yellowish-brown setae, except glabrous central area. Scutellum with dense golden pubescence.

ELYTRA. Coarsely, sparsely punctate, with a long erect, yellowish-brown seta emerging from each puncture (punctures and setae absent on light areas); surface lacking pubescence; apex subtruncate, slightly emarginate centrally.

LEGS. Femora pedunculate-clavate, with long, erect, sparse yellowish-brown setae. Tibiae with both, short and long, abundant yellowish-brown setae, except posterior area of ventral surface with dense, bristly yellowish-brown pubescence. Metatarsomere I slightly longer than II-III together. 

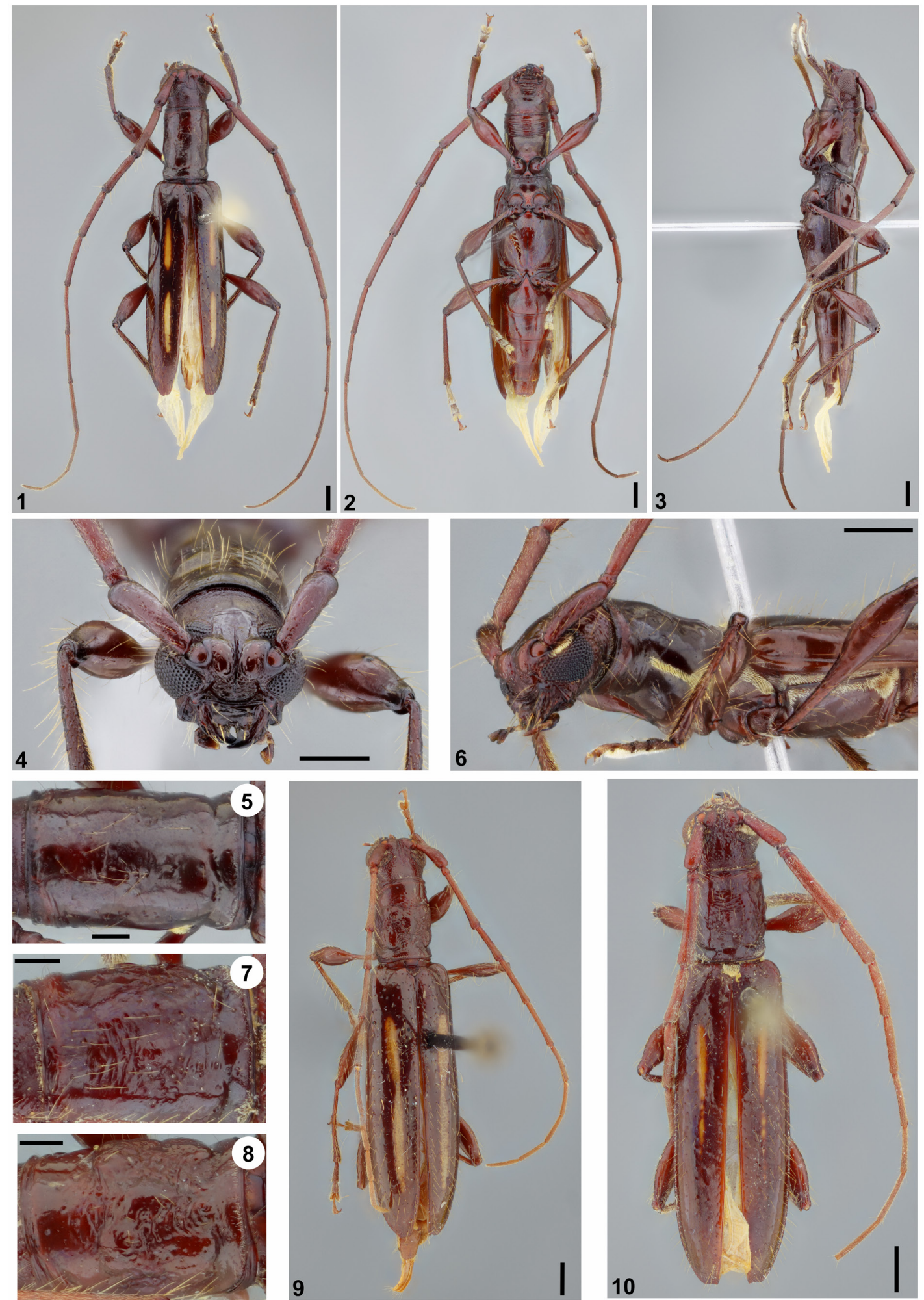

Figs 1-10. 1-6. Heterachthes caceresae sp. nov. 1-5. Holotype, $\widehat{\jmath}$ (RBINS 34.248). 1. Habitus, dorsal view. 2. Habitus, ventral view. 3. Habitus, lateral view. 4. Head, frontal view. 5. Pronotum. 6. Paratype, $\sigma^{\lambda}$ (MZSP). Partial lateral habitus. - 7-10. Heterachthes viticulus Martins, 1970. 7. Paratype, đ̊ (MZSP), pronotum. 8. Paratype, $q$ (MZSP), pronotum. 9. Paratype, $q$ (MZSP), dorsal habitus. 10. Paratype, ${ }^{\lambda}$ (MZSP), dorsal habitus. Scale bars: $1-4,6,9-10=1.0 \mathrm{~mm} ; 5,7-8=0.5 \mathrm{~mm}$. 
AвDOMEN. Ventrites with minute, sparse yellowish-white setae, sparser centrally, and long, erect, sparse yellowish-brown setae on about posterior half (about posterior $3 / 4$ on ventrite I); apical margin of ventrite $\mathrm{V}$ truncate, slightly concave centrally.

\section{Remarks}

We consider that the presence of 12 segments in the antennae is a variation or aberration in the holotype. This is because the $12^{\text {th }}$ antennomere on the right antenna is not distinctly separate from the $11^{\text {th }}$, and the paratype has the antennae distinctly 11-segmented.

Subfamily Lamiinae Latreille, 1825

Tribe Acanthocinini Blanchard, 1825

Genus Lagocheirus Dejean, 1835

\section{Lagocheirus araneiformis parvulus Casey, 1913 revalidated}

Figs 11-12

Cerambyx ypsilon Voet, 1778?: 11 (nom. nud.).

Lagochirus parvulus Casey, 1913: 304.

Lagocheirus stroheckeri granulatus Dillon, 1956: 139.

\section{Material examined}

HONDURAS • 2 q ; ; Cortés, Cusuco National Park, Santa Thomas, transect 2; 20 Jul. 2015; beginning of night, 'disturbed forest'; L. Geeraert and M. Jocqué leg.; RBINS.

\section{Remarks}

Voet (1778?) described Cerambyx ypsilon (Fig. 11) from "America septentrionali". According to SantosSilva et al. (2010) on Polyrhaphis spinosa (Drury, 1773) (translated from Portuguese): “...it is worth noting that this work was successively added to new parts from 1766 onward and, contrary to what appears in almost all the catalogs on Cerambycidae, many species are before 1778 and were already published in 1776 (Beckmann 1776). Sherborn (1902) was probably the first to report that Voet's work (op. cit.) did not follow the binominal system ... Anyway, in relation to Polyrhaphis spinosa, the name used by Voet (op. cit.), only appeared after 1776 because, according to Beckmann (op. cit.), in that year the work only included 14 species in Cerambyx and eight pages (Cerambyx horridus was published on page 15, as species number 59). With the death of Johannes Eusebius Voet, in 1778, the work was unfinished, but in 1796 volume II, in which Cerambyx was addressed, already had 24 pages and 24 prints (Dryander \& Banks 1796). As the work did not undergo additions between 1778 (Voet's passing) and 1804 [British Museum (Natural History) 1915], Voet had undoubtedly already included Cerambyx horridus [= Polyrhaphis spinosa] in his work." The same reasoning can be used regarding Cerambyx ypsilon, which was published on page 11 (Latin part). Nevertheless, the names published by Voet (17661806) cannot be considered as nomenclaturally available, as has been indicated by some authors, for example, Alonso-Zarazaga \& Lyal (1999), Santos-Silva et al. (2010), and Krell (2012).

Schönherr (1817) synonymized Cerambyx ypsilon with Cerambyx araneiformis Linnaeus, 1767. Dillon (1956) described Lagocheirus stroheckeri granulatus based on males and females from the USA (Texas), and Linsley \& Chemsak (1995) synonymized it with L. araneiformis ypsilon. Dillon (1957) considered C. ypsilon as a subspecies of Lagocheirus araneiformis, without comment about the synonymy proposed by Schönherr (1817), which is also present in Aurivillius (1922), and Blackwelder (1946). In the same work, Dillon (1957) synonymized L. parvulus with L. araneiformis ypsilon, which was described by Casey (1913) based on a single male from Panama. Currently, the species is known as Lagocheirus araneiformis ypsilon, with L. parvulus, and L. stroheckeri granulatus as junior synonyms. 
It is not possible to be sure whether Cerambyx ypsilon is really synonymous with Lagocheirus parvulus Casey, 1913 (generic name published as Lagochirus, attributed to Erichson (1847), but Lagocheirus is by Dejean (1835)). This is because the short description and drawing in Voet (1778?) do not allow confirmation. Unfortunately, Voet's collection is probably lost; according to Santos-Silva et al. (2010) discussing Polyrhaphis armiger (Schönherr, 1817) (translated from Portuguese): “According to British Museum (Natural History) (1915), the stock from Johannes Eusebius Voet was acquired by Bakhuysen in 1804. We do not know whether Voet's insect collection was part of the material acquired by G. Bakhuysen, but according to Reichard (1827), this insect collection remained in La Haye: "La Haye. Cette ville, qui n'a ni murs ni portes, est entourée d'un large fossé sur lequel on a pratiqué des ponts-levis. Elle surpasse néanmoins plusieurs villes célèbres par la magnificence de ses bâtimens et ses autres ornemens. Curiosités: ... les cabinets d'insectes de MM. Voet et Meuschen, le cabinet de conquillages de M. Lyonnet"... [The Hague. This city, which has neither walls nor gates, is surrounded by a wide moat over which drawbridges have been made. It nevertheless surpasses several famous cities by the magnificence of its buildings and its other ornaments. Curiosities: ... the insect cabinets of Voet and Meuschen, the cabinet of shells of Mr. Lyonnet ...]." However, it is not within the scope of this work to verify previously proposed synonymies, but only to solve the problem related to the correct name of the species/subspecies. As Lagocheirus parvulus is the oldest available name, it is used instead of "ypsilon". Accordingly, the name of the subspecies is L. araneiformis parvulus.

The specimens from Honduras examined by us (Fig. 12) agree well with several specimens identified as L. araneiformis ypsilon in MZSP collection. However, comparing the original description of L. stroheckeri Dillon, 1956 (currently, L. araneiformis stroheckeri), as well as photographs of the holotype and allotype of this species with the specimens usually identified as L. a. ypsilon, the only reliable difference we have found is the more angulate humerus in L. stroheckeri. This suggests that
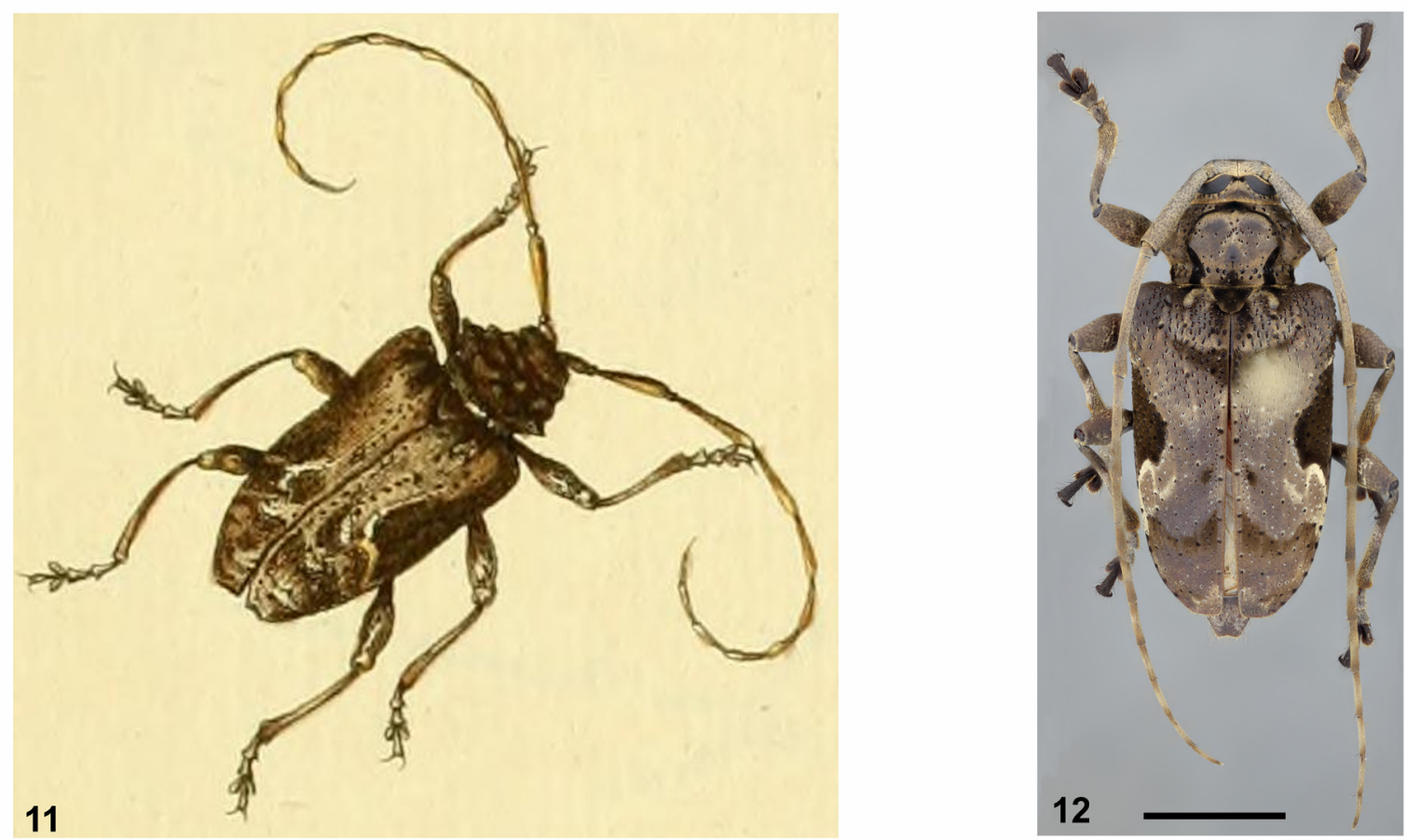

Figs 11-12. Lagocheirus araneiformis parvulus Casey, 1913. 11. Cerambyx ypsilon from Voet (1778?). 12. Female from Honduras (RBINS). Dorsal habitus. Scale bar $=5.0 \mathrm{~mm}$. 
the current subspecies of $L$. araneiformis need a full revision because at least part of them may be just variations of the same taxon (especially $L$. stroheckeri, which is probably synonymous with $L$. parvulus).

Tribe Acrocinini Swainson, 1840

Genus Oreodera Audinet-Serville, 1835

Oreodera kawasae sp. nov. urn:1sid:zoobank.org:act:288B901E-3535-41F8-A35C-E6A89184364F

Figs 13-19

\section{Diagnosis}

The general appearance of Oreodera kawasae sp. nov. is much as that of O. turnbowi McCarty, 2001. However, although McCarty (2001) had only provided the length of the holotype male and paratype female, it is possible to see, using photographs of the holotype (see Bezark 2021b), that O. turnbowi is proportionally more slender than $O$. kawasae sp. nov. Additionally, comparing the males of $O$. kawasae sp. nov. with the holotype male of $O$. turnbowi, it is possible to provide the following differences: distance between upper eye lobes equal to maximum width of the scape; antennomeres VII and IX not ringed with white pubescence basally; anterolateral tubercles of the prothorax with apex noticeably rounded; elytra at most 4.0 times prothoracic length; centrobasal crest of the elytra not distinctly separated into two tubercles; tarsomeres $\mathrm{V}$ shorter and distinctly widened. In the holotype male of O. turnbowi, distance between upper eye lobes shorter than maximum width of scape, antennomeres VII and IX distinctly ringed with whitish pubescence basally, anterolateral tubercles of the prothorax nearly conical, elytra is almost 4.5 times prothoracic length, centrobasal crest of the elytra distinctly separated into two distinct tubercles (with punctures between them), and the tarsomeres $\mathrm{V}$ are longer and slender. According to McCarty (2001), the mesoventral process in O. turnbowi is 1.25 times as wide as the mesocoxal cavity. As we do not know where the width was measured (narrowest area or apex), we are not using this difference (in $O$. kawasae sp. nov., 1.3 times in the narrowest area, 1.5 times in apex).

Oreodera kawasae sp. nov. is also similar to O. noguerai McCarty, 2001, but differs by some of the same characters attributed to $O$. turnbowi (body proportions, pubescence on antennomeres VII and IX. Unfortunately, O. noguerai is known only from the holotype female, while $O$. kawasae sp. nov. is known only from males, but it also differs by the antennomere III being about 0.7 times as long as scape (twice as long as scape in $O$. noguerai), and apical half of elytral margin without a fringe of sparse, fine, erect setae (present in $O$. noguerai).

The general appearance of $O$. kawasae sp. nov. is somewhat similar to that of $O$. advena Martins \& Galileo, 2005, O. basipenicillata Tippmann, 1960, O. undulata Bates, 1861, and O. clarkei Galileo, Santos-Silva \& Wappes, 2017 (see photographs of these four species on Bezark 2021b), but differs from them especially by the elytral pubescence pattern, and protarsal length and shape.

\section{Etymology}

This species is named after Blanca Jeannette Kawas Fernández (Jeanette Kawas for short) in honor of her never-ending efforts to conserve the fauna and flora of Honduras. She co-established the Prolansate Foundation, which is still committed to protecting the environment while improving the quality of life of the local communities. Jeanette was murdered at her home in February 1995.

\section{Type material}

\section{Holotype}

HONDURAS • ○ं; Cortés, Cusuco National Park (Base camp); 7 Jul. 2017; local collector leg.; RBINS 34.248 . 


\section{Paratypes}

HONDURAS - Cortés • 1 đ̊; Cusuco National Park; Jun.-Jul. 2015; local collector leg.; RBINS 34.248 - 1 ơ; Cusuco National Park; 17 Jul. 2015; ETC leg.; RBINS 34.248 • 1 ơ; Cusuco National Park, Guanales, in camp; 3 Aug. 2015; local collector leg.; MZSP・ 1 ते; Cusuco National Park, Capuca; 2015; local collector leg.; RBINS 34.248 • 1 今ं; Cusuco National Park, Base camp; 8 Jun. 2015; T. Brown leg.; RBINS 34.248 • 1 §; Cusuco National Park; 1 Jul. 2017; local collector leg.; MZSP • 1 §; Cusuco National Park, Cantilles; Jun.-Aug. 2015; local collector leg.; RBINS 34.248 • 1 §ं; Cusuco National Park; 6 Jun. 2017; local collector leg.; RBINS 34.248 • 1 q; Cusuco National Park, Base Camp transect 3; $15.494^{\circ} \mathrm{N}, 88.214^{\circ} \mathrm{W}$; 1513 m a.s.l.; 24 Jun. 2013; Michelle D’Souza leg.; Barcode of Life DNA Voucher specimen; BIN: BOLD ACJ7715, BOLD Proc. ID: GMHGE319-13; CBG.

Measurements in mm (male holotype/male paratypes (8))

Total length, 13.55/8.40-13.95; prothoracic length, 2.35/1.45-2.65; anterior prothoracic width, 2.70/1.65-2.85; posterior prothoracic width, 3.35/2.00-3.90; maximum prothoracic width (between apex of tubercles), 4.05/2.40-4.40; humeral width, 5.60/3.40-5.95; elytral length, 9.75/6.05-9.90.

\section{Description}

Male holotype (Figs 13-17)

COLORATION. Integument mostly dark brown; mouthparts reddish brown, except blackish labial palpomere II, basal half of labial palpomere III, maxillary palpomeres II-III, and basal half of maxillary palpomere IV; antennomeres brown, especially from IV; apex of abdominal ventrites I-IV reddish brown.

HEAD. Frons densely micropunctate; with yellowish-brown pubescence partially obscuring integument, glabrous along median groove, with one long, erect seta of same color on each side close to eyes. Vertex and area behind upper eye lobes densely micropunctate (punctures slightly more distinct and sparser close to prothorax); with yellowish-brown pubescence, obscuring integument on some areas, yellower close to eyes, and forming irregular, slightly distinct yellowish-white macula behind upper eye lobes on area closer to prothorax. Area behind lower eye lobes with dense yellowish pubescence on wide area close to eye (pubescence more yellowish-white depending on light intensity), glabrous close to prothorax; with a few long, erect yellowish setae close to eye. Antennal tubercles minutely, abundantly punctate; pubescence as on frons. Genae 1.25 times length of lower eye lobes; densely micropunctate; with dense yellowish-brown pubescence (pubescence almost golden close to eye toward clypeus, yellowish-white toward ventral surface), glabrous on apex; with a few long, erect yellowish setae interspersed. Wide central area of postclypeus with pubescence as on frons, but somewhat bristly, with long, erect setae interspersed (setae brown on basal half, yellowish-white on apical half); sides glabrous. Labrum convex, coplanar with anteclypeus on posterior $2 / 3$, inclined on anterior third; finely, abundantly punctate on posterior $2 / 3$, nearly smooth on anterior third; with nearly golden pubescence on posterior $2 / 3$ (pubescence more yellowish-white depending on light intensity), with long, erect setae interspersed (setae dark brown with apex yellowish), glabrous on posterior third, and with fringe of yellow setae on anterior margin. Mandibles with dense yellow pubescence on basal $2 / 3$, with long, erect, sparse setae of same color interspersed, glabrous on apical third. Gulamentum smooth, shiny, glabrous on posterior half, depressed, opaque, densely micropunctate, with minute yellowish pubescence on anterior half. Median groove distinct from clypeus to prothoracic margin, sulcate, slightly widened between upper eye lobes. Distance between upper eye lobes 0.35 times length of scape, 0.24 times distance between outer margins of eyes; in frontal view, distance between lower eye lobes 0.87 times length of scape, 0.60 times distance between outer margins of eyes. Antennae 2.0 times elytral length, reaching elytral apex at apex of antennomere VII. Scape and pedicel with dense greenish-yellow pubescence dorsally and laterally (pubescence more yellowish-brown depending on light intensity), mostly yellowish-white ventrally; with long, erect, sparse setae ventrally (setae dark basally, yellowish 
apically), present on posterior half of scape, throughout on pedicel. Basal half of antennomeres III-IV with yellowish pubescence dorsally, white pubescence on sides and ventral surface of anterior $2 / 3$, and greenish-brown pubescence on remaining surface; with long, erect setae ventrally (setae dark basally, yellowish apically). Antennomeres V, VI, VIII, and X with white pubescence on basal third, slightly distinct, brownish on remaining surface; with a few long, erect brownish setae apically; with short, erect, sparse yellowish setae throughout. Antennomeres VII and IX with slightly conspicuous brownish pubescence throughout, a few long, erect brownish setae apically, and with short, erect, sparse yellowish setae throughout. Antennomere XI with brownish pubescence, with whitish pubescence interspersed near base, and short, sparse, erect yellowish setae interspersed throughout. Antennal formula (ratio) based on length of antennomere III: scape $=0.67$; pedicel $=0.23 ; \mathrm{IV}=0.79 ; \mathrm{V}=0.63 ; \mathrm{VI}=0.63 ; \mathrm{VII}=$ $0.60 ; \mathrm{VIII}=0.59 ; \mathrm{IX}=0.56 ; \mathrm{X}=0.53 ; \mathrm{XI}=0.45$.

Thorax. Lateral tubercles large, with blunt apex. Pronotum with five large, elevated tubercles: one circular on each side near middle, with rounded apex (these are highest); one elongate placed centrally on posterior half; and one circular, with blunt apex on each side of posterior third (smaller and far from each other than those placed near middle). Pronotal surface with row of coarse and deep punctures near posterior margin, coarse, moderately abundant punctures near anterior margin (slightly finer than on posterior row), and coarse, sparse punctures surrounding tubercles (finer than punctures near anterior and posterior margins); central area with mostly greenish-brown pubescence, and sides and anterior and posterior areas with mostly yellowish-brown pubescence (more pale yellow on some areas, especially toward lateral tubercles of prothorax). Sides of prothorax coarsely, abundantly punctate anteriorly and posteriorly, smooth centrally; with abundant yellowish-brown pubescence not obscuring integument (appearing to be lighter on some areas depending on light intensity); area behind lateral tubercle with long, erect, sparse dark setae. Prosternum with yellowish-brown pubescence, denser laterally. Prosternal process with pale yellow pubescence not obscuring integument (appearing to be yellowishwhite depending on light intensity), distinctly denser on posterior half; narrowest area 0.6 times width of procoxal cavity. Mesoventrite with pale yellow pubescence not obscuring integument, except sides with dense yellowish-brown pubescence; mesanepisternum, mesepimeron, and metanepisternum with dense yellowish-brown pubescence (nearly golden depending on light intensity). Narrowest area of mesoventral process 1.3 times width of mesocoxal cavity; apex of mesoventral process 1.5 times width of procoxal cavity. Metaventrite distinctly tumid on sides of posterior $2 / 3$; with pale yellow pubescence on anterocentral area and between tumid areas, dense, yellow on tumid areas, yellowish-brown on remaining surface; sides coarsely, sparsely punctate (punctures more abundant on tumid areas). Scutellum semicircular; with short yellowish-brown pubescence on basal $2 / 3$, slightly longer, dense, yellow on posterior third.

ELYTRA. Humeri projected laterally; surface coarsely, abundantly punctate on basal seventh, somewhat finely, sparsely punctate centrally from remaining basal third, coarsely sparsely punctate on remaining surface (punctures distinctly coarser than on basal seventh); apex obliquely truncate; surface, between apex of basal seventh and apex irregularly rugose; with transverse, elevated crest dorsally on apex of basal seventh, slightly more elevated toward its apex, with dense tuft of setae on top (setae yellow basally, black apically, longer on outer area, shorter on inner area, nearly absent between them); circumscutellar region mostly with white pubescence; sides of basal seventh with yellowish-brown pubescence, more yellowish or greenish-brown on some areas; dorsal surface with large, wide Y-shaped white band from about apex of anterior third to about posterior quarter; sides of central area with white pubescence laterally, partially surrounding irregular yellow pubescent macula placed centrally; sides of posterior quarter with nearly $\mathrm{V}$-shaped white pubescent macula; area close to suture on posterior quarter with white pubescent macula; remaining elytral surface mostly with yellowish-brown and greenish-brown pubescence, except subcircular brownish pubescent maculae centrally, close to lateral arms of Y-shaped white band. 

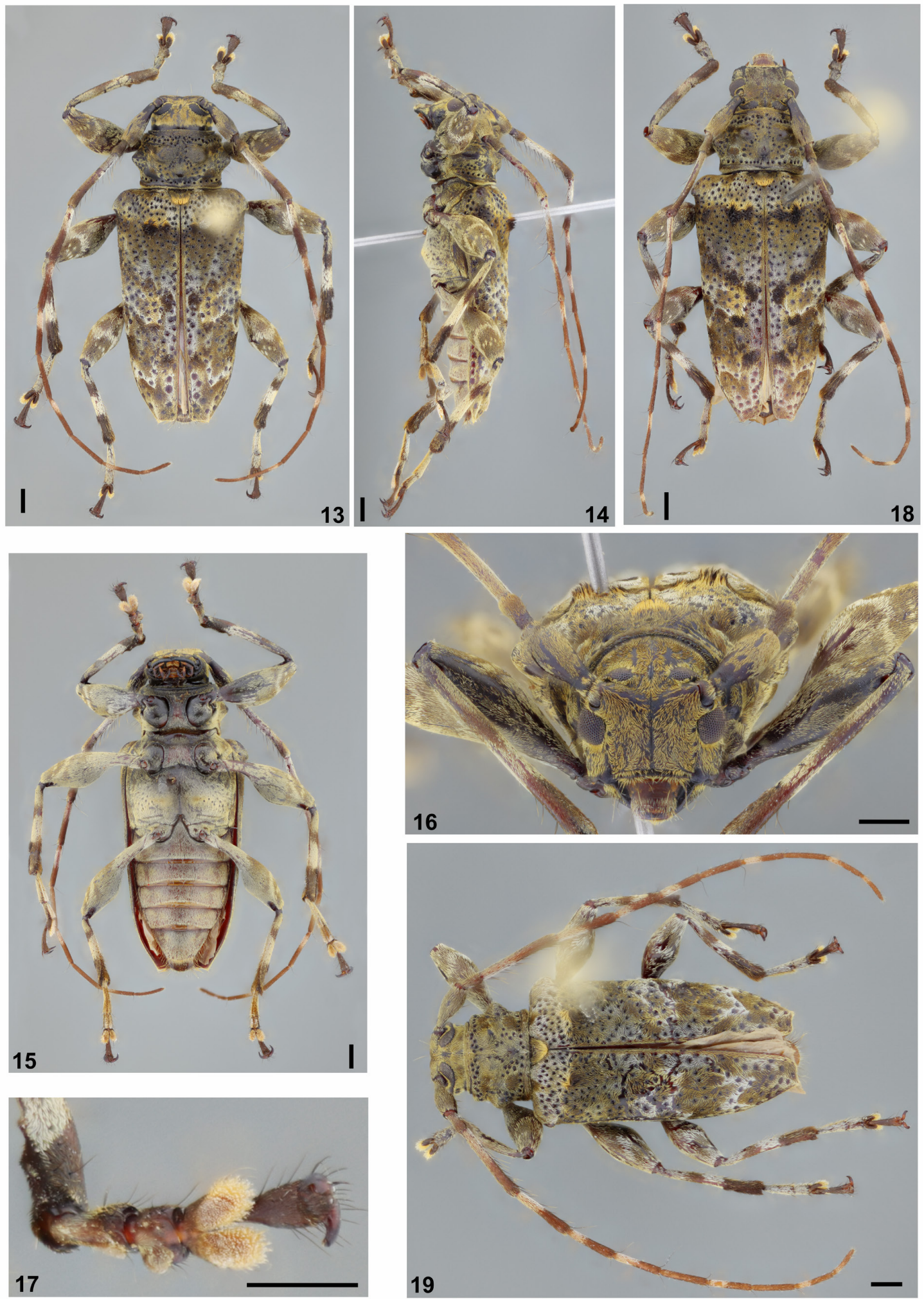

Figs 13-19. Oreodera kawasae sp. nov. 13-17. Holotype, đ̊ (RBINS 34.248). 13. Habitus, dorsal view. 14. Habitus, lateral view. 15. Habitus, ventral view. 16. Head, frontal view. 17. Protarsus. 18-19. Male paratypes, dorsal habitus. 18. Specimen 1 (MZSP), habitus, dorsal view. 19. Specimen 2 (MZSP), habitus, dorsal view. Scale bars $=1.0 \mathrm{~mm}$. 
Legs. Femora mostly with greenish-brown pubescence (appearing to be lighter depending on light intensity), with arched pale yellow pubescent ring on middle of club, and small pale yellow pubescent spots between it and apex. Tibiae with light yellowish-brown pubescent ring on basal third (protibiae) or quarter (meso- and metatibiae), ring with yellowish-white pubescence centrally, ring with sparse brownish pubescence between previous rings, sparse brownish pubescence dorsally and laterally on posterior quarter, bristly yellowish-brown pubescence ventrally on posterior quarter; posterior quarter of ventral surface of protibiae sinuous, with distinct projection on base of this area; dorsal surface of posterior quarter of meso- and metatibiae with short, erect, thick black setae dorsally. Protarsi not noticeably long; inner side of tarsomere II with distinct projection (Fig. 17). Tarsomeres I-II with pale yellow pubescence; tarsomeres III-V with brownish pubescence, shorter and sparser than on anterior segments; metatarsomere I slightly longer than II-III together.

ABDOMEN. Ventrites with yellowish pubescence, partially obscuring integument, denser laterally, except glabrous apex of I-IV; apex of ventrite V rounded (slightly more projected centrally).

\section{Variation (Figs 18-19)}

Pubescence on vertex moderately greenish-brown; dense yellow pubescence on scutellum from covering almost entire surface to present only at apex; elytral pubescence somewhat variable, especially shape of white pubescent bands, and number of brownish subcircular areas, which may be very distinct, almost forming oblique band close to arms of Y-shaped white pubescent band, and posterior area of central white pubescent band.

\section{Sequence information}

A specimen from CNP of this species has been sequenced by the Centre for Biodiversity Genomics (CBG) as part of a separate project (D'Souza \& Hebert 2018, project doi: https://doi.org/10.5883/DS-MECNP), but until now it has remained unidentified. The sequence (Cytochrome Oxidase Subunit 15 ' Region) can be accessed through the BOLDSystems database, with ID number GMHGE319-13.

\section{Remarks}

Apparently, the new species is somewhat common. Therefore, it is likely that there are many specimens incorrectly identified in the collections.

Tribe Apomecynini Thomson, 1860

Genus Phrynidius Lacordaire, 1869

Phrynidius guifarroi sp. nov. urn:1sid:zoobank.org:act:A45ED7C3-2D75-4648-A768-4B1C64F1768F

Figs $20-25$

\section{Diagnosis}

Phrynidius guifarroi sp. nov. is similar to P. jonesi Gutiérrez, Toledo-Hernández \& Noguera, 2020 (Figs 26-30), but differs as follows: pronotum with wide, elevated crest centrally, from anterior fifth to after middle, with its dorsal surface rugose and uniformly convex (Figs 24-25); elytra with nearly glabrous area on basal fifth, close to scutellum and suture; and posterior tubercles of the elytra smaller. In P. jonesi, the central crest of the pronotum is nearly conical, placed before the middle (Fig. 26), elytra with large nearly glabrous area placed centrally, and posterior tubercles of the elytra distinctly larger.

\section{Etymology}

This species is named after Mario Guifarro from Olancho, Honduras, a hunter and gold miner who turned into a dedicated conservationist when he experienced the degradation of rainforests in eastern Honduras. He was murdered in Moskitia in 2007 while setting up a protected forest zone. 


\section{Type material}

\section{Holotype}

HONDURAS • +; Cortés, Cusuco National Park, Danto, close to camp; 29 Jun. 2015; M. Jocqué leg.; RBINS 34.248.

\section{Paratype}

HONDURAS • +; Cortés, Cusuco National Park, Base Camp, Transect 4; 14 Jul. 2015; T. Brown leg.; MZSP.

\section{Measurements in mm (female holotype/ female paratype)}

Total length, 11.25/12.05; prothoracic length, 3.05/3.45; anterior prothoracic width, 2.65/3.10; posterior prothoracic width, $2.60 / 2.90$; widest prothoracic width, $3.10 / 3.45$; humeral width, $2.70 / 3.10$; elytral length, $7.30 / 7.85$.

\section{Description}

\section{Female holotype (Figs 20-24)}

COLORATION. Integument mostly black dorsally and laterally, mostly dark brown ventrally; head mostly black except apex of labrum orangish brown, basal area of anteclypeus, parts of labium, and apex of palpomeres reddish brown; scape, pedicel, and antennomeres III-IV dark brown; remaining antennomeres dark reddish brown. Posterocentral area of pronotum dark reddish brown. Scutellum orangish brown.

HeAD. Frons with dense pale yellowish-brown pubescence obscuring integument, and short, sparse whitish setae interspersed. Vertex and area behind eyes coarsely, sparsely punctate; with dense pale yellowish-brown pubescence obscuring integument, except glabrous median groove. Antennal tubercles moderately elevated, slightly separated from each other, together forming V-shaped sulcus; pubescence as on frons, except narrow glabrous apex. Median groove distinct from clypeus to prothoracic margin (more distinct on vertex). Genae coarsely, sparsely punctate; with dense pale yellowish-brown pubescence except narrow glabrous apex. Wide central area of postclypeus with pubescence as on frons, with long, erect brownish setae near anteclypeus; sides glabrous. Labrum coplanar with anteclypeus at posterior $2 / 3$, inclined at anterior third; posterior $2 / 3$ smooth close to anteclypeus, finely punctate close to inclined area; with very sparse yellowish-white pubescence on posterior $2 / 3$, nearly glabrous close to anteclypeus, and long, erect yellowish-brown setae directed forward close to inclined area; anterior third with moderately short and abundant nearly golden setae. Gulamentum glabrous except narrow anterior area with pale yellowish-brown pubescence not obscuring integument. Lower eye lobes 0.43 times as long as genal length; distance between upper eye lobes 0.42 times length of scape, 0.40 times distance between outer margins of eyes; in frontal view, distance between lower eye lobes 0.75 times length of scape, 0.71 times distance between outer margins of eyes. Antennae 1.55 times elytral length, almost reaching elytral apex. Scape, pedicel, antennomere III, and basal $4 / 5$ of IV with dense pale yellowishbrown pubescence obscuring integument, and short, sparse, decumbent or arched yellowish-white and brown setae interspersed; apical fifth of antennomere IV, and remaining antennomeres with very sparse yellowish-white pubescence. Antennal formula (ratio) based on length of antennomere III: scape $=0.98$; pedicel $=0.09 ; \mathrm{IV}=0.81 ; \mathrm{V}=0.32 ; \mathrm{VI}=0.30 ; \mathrm{VII}=0.30 ; \mathrm{VIII}=0.28 ; \mathrm{IX}=0.30 ; \mathrm{X}=0.26 ; \mathrm{XI}=0.28$.

Thorax. Prothorax as long as wide; sides arched on anterior quarter, slightly convergent, irregular on posterior $3 / 4$. Pronotum entirely rugose; in lateral view, distinctly, gradually elevated from anterior margin to near middle, then distinctly, gradually inclined toward posterior margin; with wide, elevated crest centrally, from anterior fifth to after middle, with its dorsal surface rugose and uniformly convex; coarsely, moderately abundantly punctate; with dense pale yellow pubescence, not obscuring punctures, except nearly glabrous posterocentral area, and small, irregular glabrous area on each side of middle. 
Sides of prothorax entirely rugose; coarsely, moderately abundantly punctate; with dense pale yellowishbrown pubescence not obscuring punctures. Prosternum with dense pale yellowish-brown pubescence obscuring integument laterally, moderately sparser centrally. Prosternal process gradually widened from base to posterior quarter, strongly, moderately abruptly widened on posterior quarter; with dense pale yellowish-brown pubescence, and irregular areas with slightly sparser pubescence interspersed. Central area of mesoventrite with moderately abundant pale yellowish-brown pubescence distinctly not obscuring integument; sides of mesoventrite, mesanepisternum, mesepimeron, metanepisternum, metaventrite, and mesoventral process with dense pale yellowish-brown pubescence; mesanepisternum coarsely, moderately sparsely punctate; apex of mesoventrite emarginate centrally; metaventrite with short, decumbent, sparse yellowish-white setae interspersed. Scutellum very narrow, transverse, glabrous.

ELYTRA. Entirely rugose, coarsely, deeply, moderately abundantly punctate; widest area (without tubercles) 1.8 times humeral width; with large conical tubercles, with glabrous apex; surface with dense pale yellowish-brown pubescence, except glabrous apex of tubercles and glabrous large area close to scutellum and suture on basal fifth.
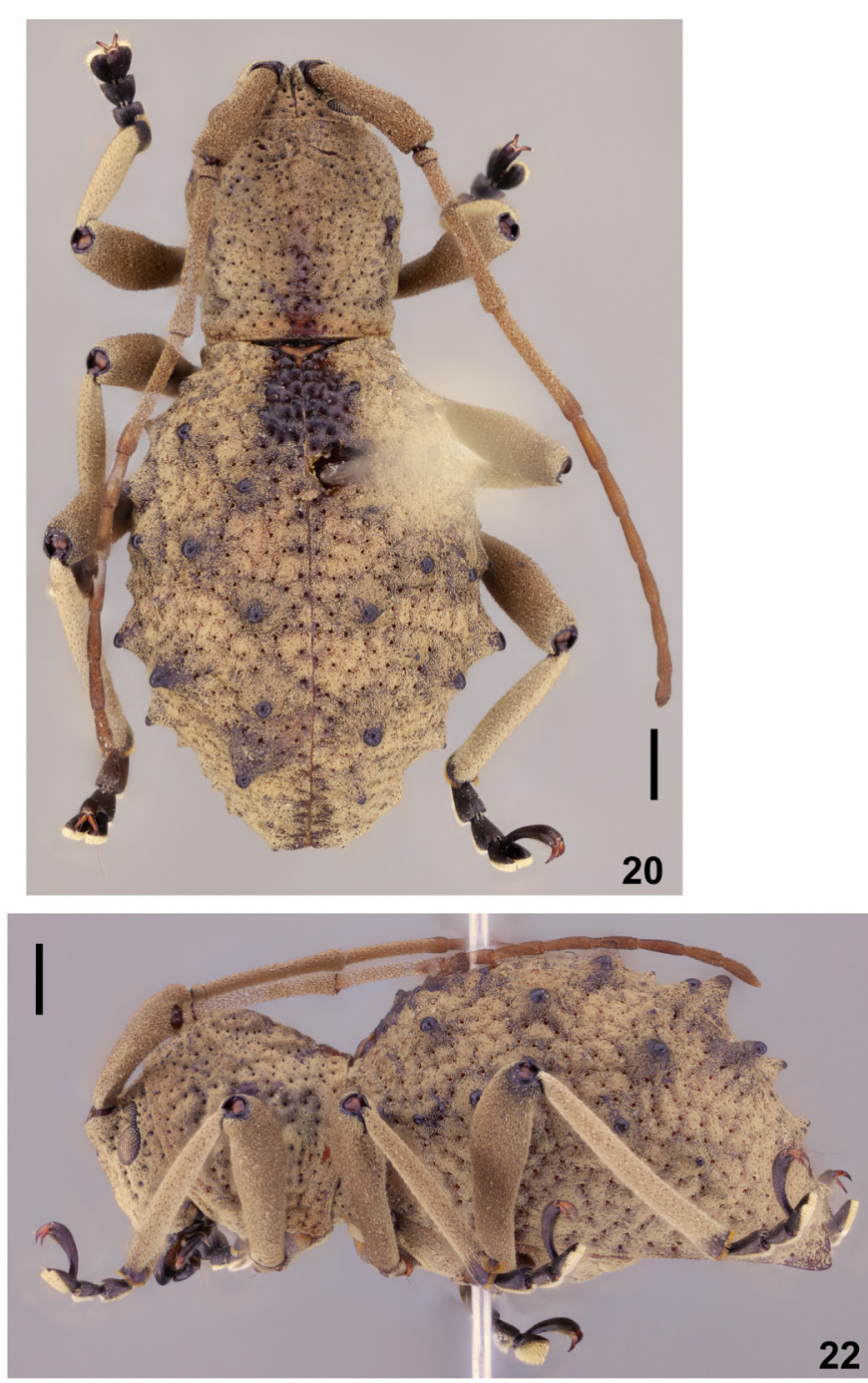
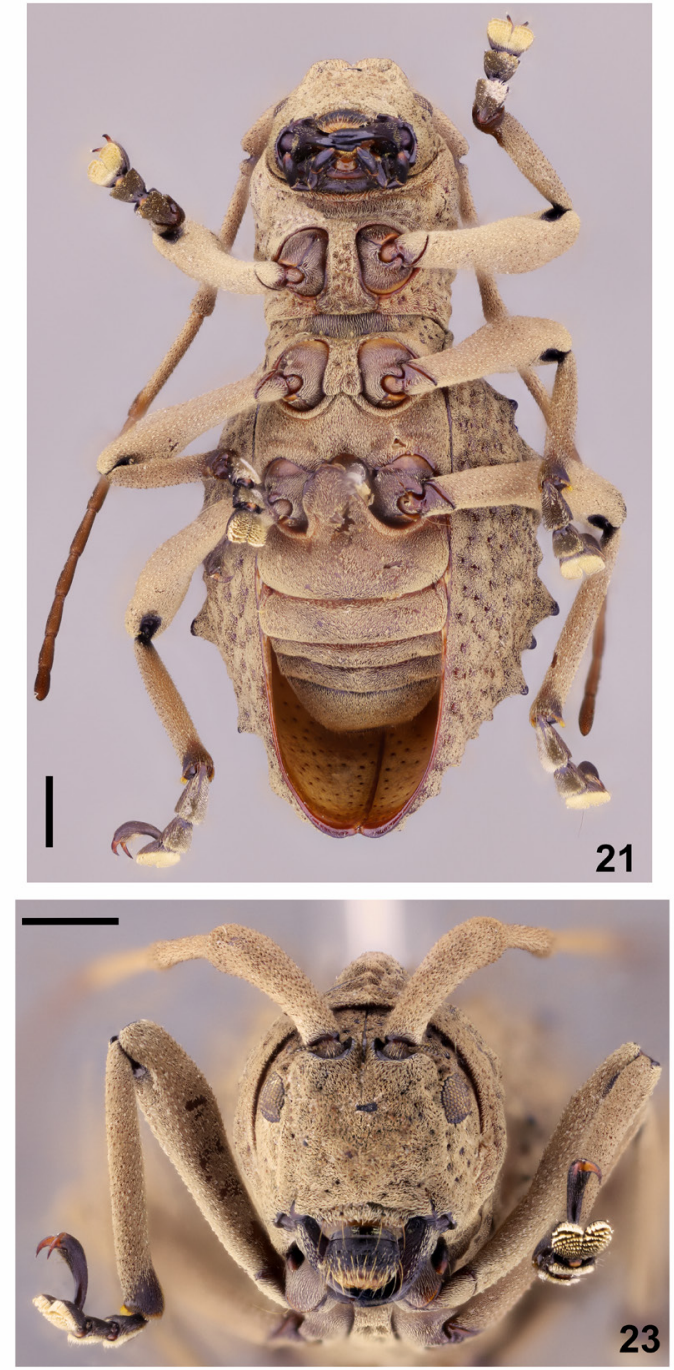

Figs 20-23. Phrynidius guifarroi sp. nov., holotype, $q$ (RBINS 34.248). 20. Habitus, dorsal view. 21. Habitus, ventral view. 22. Habitus, lateral view. 23. Head, frontal view. Scale bars $=1.0 \mathrm{~mm}$. 

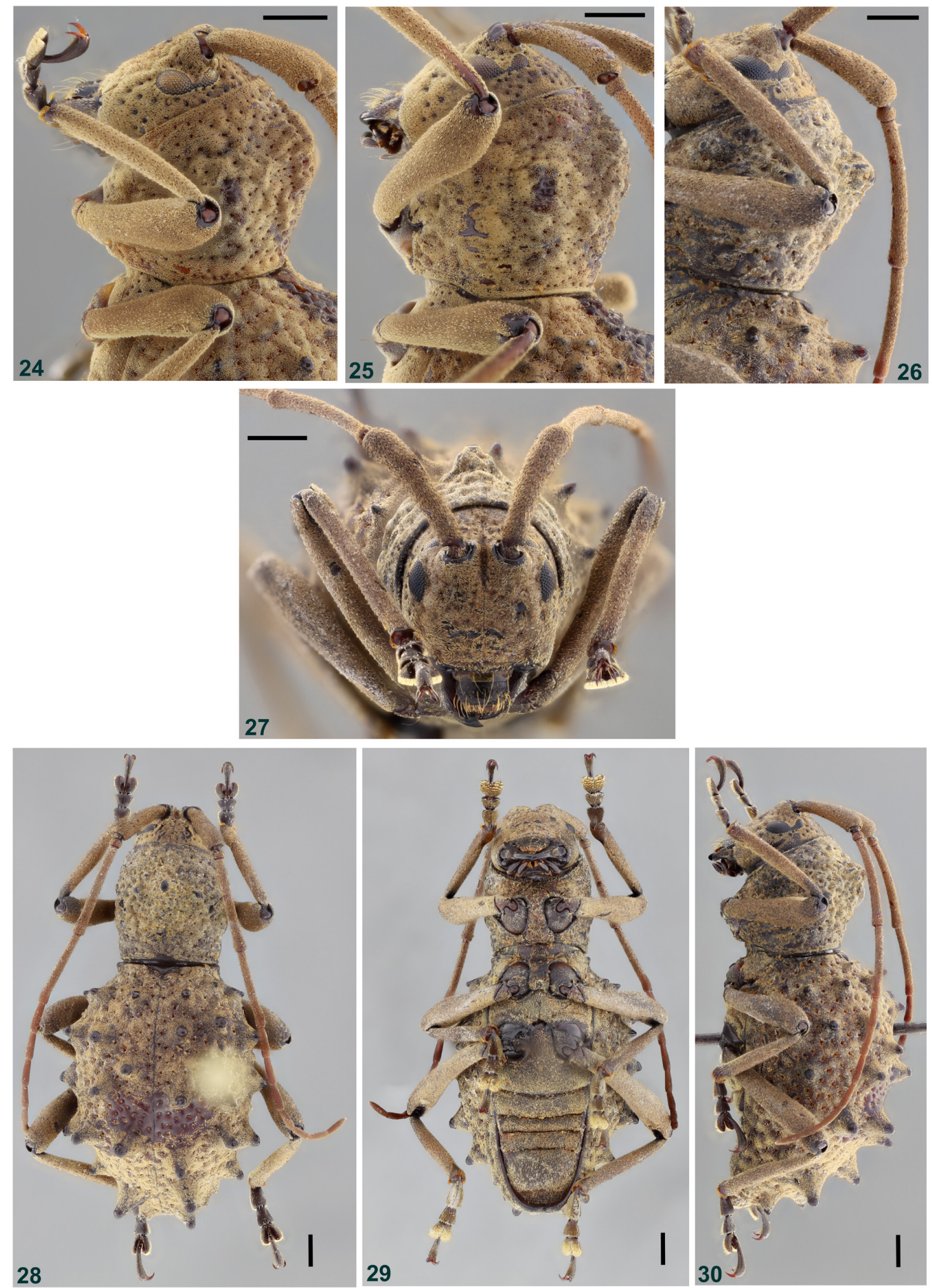

Figs 24-30. 24-25. Phrynidius guifarroi sp. nov., prothorax, lateral view. 24. Holotype, (RBINS 34.248). 25. Paratype, + (MZSP). - 26-30. Phrynidius jonesi Gutiérrez, Toledo-Hernández \& Noguera, 2020, $\widehat{\partial}$ (FSCA). 26. Prothorax, lateral view. 27. Head, frontal view. 28. Habitus, dorsal view. 29. Habitus, ventral view. 30. Habitus, laetral view. Scale bars $=1.0 \mathrm{~mm}$. 
Legs. Femora with dense pale yellowish-brown pubescence, glabrous or almost so on apex, and short, decumbent yellowish-white setae interspersed. Tibiae with dense light beige pubescence, and short, decumbent yellowish-white setae interspersed, except almost glabrous area close to apex; apical margin of all tibiae, and dorsal area close to apex of mesotibiae with thick, nearly golden setae. Dorsal surface of tarsomeres with minute, slightly distinct yellowish-brown pubescence, not obscuring integument; central area of apex of tarsomeres I and II with two pairs of short, thick yellowish setae.

ABDOMEN. Ventrites with dense pale yellowish-brown pubescence.

\section{Remarks}

The male of $P$. jonesi examined by us is from the same Mexican state as the holotype (Gutiérrez et al. 2020): “Chiapas: Montebello lake area, 15-16.VI.1987, J.E. Wappes leg.” (ACMT).

Tribe Hemilophini Thomson, 1860

Genus Arixiuna Martins \& Galileo, 1992

Arixiuna varians (Bates, 1881)

Hemilophus varians Bates, 1881a: 222.

Hemilophus varians - Bates 1881b: 305. - Lameere 1883: 78 (cat.). — Aurivillius 1923: 587. Blackwelder 1946: 623 (checklist). — Chemsak \& Linsley 1970: 411 (lect.). — Chemsak et al. 1992: 159 (cat.). — Gilmour 1965: 634 (cat.). — Noguera \& Chemsak 1996: 408 (cat.).

Arixiuna varians - Martins \& Galileo 1992: 127. — Monné \& Giesbert 1994: 282 (checklist). — Monné 1995: 14 (cat.); 2005: 453 (cat.); 2021: 664 (cat.). — Hovore 2006: 378 (distr.). — Monné \& Hovore 2006: 256 (checklist). — Swift et al. 2010: 57 (distr.). — Bezark 2021a: 302.

\section{Material examined}

HONDURAS • 1 đ̊; Cortés, Cusuco National Park, Base camp; 10 Jun. 2017; ED. Leg.; RBINS. New formal country record

\section{Remarks}

Bates (1881a) described H. varians based on a series of males and females from Mexico and Guatemala, and reported on the elytral color (translated from Latin): "Elytra entirely fulvous, or posteriorly black and fulvous anteriorly, or with the humerus fulvous [remaining surface black]."

Martins \& Galileo (1992), erected Arixiuna, and separated it from Hemilophus Audinet-Serville, 1835 by the absence of whitish pubescence on sides of the elytra (present in Hemilophus), and from Cuicirama Martins \& Galileo, 1992 by the non orthogonal humerus (orthogonal in Cuicirama) (Martins \& Galileo 1992). Later, Galileo \& Martins (2005) described Hemilocrinitus and separated it from Arixiuna especially by the antennal tubercles close to each other (distant in Arixiuna).

Hovore (2006) reported the geographical distribution of Arixiuna varians as "eMEX (VC), GUA-CR", meaning that the geographical distribution of the species is from east Mexico (Veracruz), and from Guatemala to Costa Rica. Swift et al. (2010) reported that the species occurs from Mexico (Veracruz) to Costa Rica (Heredia). Monné (2021) reported the species as present in Mexico (Veracruz), Guatemala, and Costa Rica. We think that the report by Monné is better because, although it is very probable that the species also occurs in Honduras and Nicaragua, there is no evidence. 


\author{
Subfamily Lepturinae Latreille, 1802 \\ Tribe Lepturini Latreille, 1802 \\ Genus Strangalia Dejean, 1835 \\ Strangalia lunai sp. nov. \\ urn:1sid:zoobank.org:act:3E106974-DA9C-4583-8C19-1948CF655C00
}

Figs 31-35

\title{
Diagnosis
}

The general appearance of Strangalia lunai sp. nov. is similar to that of S. beltii (Bates, 1872), S. bivittata (Bates, 1870), S. doyeni Chemsak \& Linsley, 1976, S. eickworti Chemsak \& Noguera, 1997, S. elegans Giesbert, 1997, S. emaciata (Bates, 1880), S. instabilis Giesbert, 1985, S. occidentalis Linsley \& Chemsak, 1976, S. pectoralis (Bates, 1885), S. picticornis (Bates, 1869), S. sallaei (Bates, 1885), S. saltator (Bates, 1885), S. sexocellata Hovore \& Chemsak, 2005, and S. veracruzana Hovore \& Chemsak, 2005 (see photographs on Bezark 2021b). Males of the new species differ from those of S. beltii, S. bivittata, S. elegans, S. picticornis, S. saltator, and S. veracruzana by the pronotum lacking two longitudinal dark bands (present in all these species); from $S$. doyeni by the pronotum mostly black (orange in $S$. doyeni), and by the sides of the abdominal ventrite $\mathrm{V}$ not strongly flap-shaped (noticeably flap-shaped in $S$. doyeni); from $S$. eickworti by the distal antennomeres not distinctly yellowish (distinctly yellowish in $S$. eickworti), and profemora bicolorous (unicolorous in S. eickworti); from S. emaciata by last antennomeres not distinctly yellowish (distinctly yellowish in S. emaciata), and maxillary palpomere IV not widened apically (widely expanded in S. emaciata); from $S$. instabilis by the distal antennomeres not distinctly yellowish (distinctly yellowish in $S$. instabilis), and sides of the abdominal ventrite V not strongly flap-shaped (noticeably flap-shaped in S. instabilis); from S. occidentalis by the sides of the abdominal ventrite V not strongly flap-shaped (noticeably flap-shaped in S. occidentalis); from $S$. pectoralis by the elytra proportionally longer (shorter in $S$. pectoralis); from $S$. sexocellata by the antennae only surpassing middle of elytra (reaching elytral apex in $S$. sexocellata). Males of S. sallaei are unknown. However, based on other similar species, the pronotum probably has two dark longitudinal bands and the antennae are distinctly bicolorous.

\section{Etymology}

This species is named after Carlos Antonio Luna Lùopez (Carlos Luna for short), former director of La Unidad Ambientalista (UMA) and environmental activist. He was murdered in Catacamas, May 1998.

\section{Type material}

Holotype

HONDURAS • ^`; Cortés, Cusuco National Park, Base Camp; 12 Jun. 2015; local collector leg.; RBINS 34.248 .

Measurements in mm (male holotype)

Total length, 19.50; prothoracic length, 3.00; anterior prothoracic width, 1.45; posterior prothoracic width, 2.90; humeral width, 3.50; elytral length, 11.30.

\section{Description}

Male holotype (Figs 31-35)

Coloration. Head mostly black; anterior area of clypeus orangish brown; labrum brown; mouthparts with some areas orangish brown; antennae black except ventral surface of antennomeres IX-XI partially orangish brown; mandibles black. Prothorax black except orange posterocentral macula on pronotum, most of posterolateral angles, and irregular macula on sides of prothorax, between posterolateral angles 
and coxal cavity. Mesoventrite dark brown, almost black; mesanepisternum brownish, with large orange macula near mesepimeron, and margins darkened; mesepimeron orange close to metanepisternum; mesoventral process orange except black margins. Metanepisternum brown with irregular orangish areas interspersed. Metaventrite brown (darker on large central area), except wide V-shaped orange macula anteriorly (this macula distinctly widened laterally). Scutellum brown. Elytra mostly orange, except: narrow black band along suture, from scutellum to apex; black epipleural margin, from base to near apex; macula on anterior quarter, fused with epipleural black area, following toward dorsal surface, not reaching black sutural area and humerus (anterior margin of this macula deeply notched laterally and dorsally); black semicircular macula before middle, fused with epipleural black macula, following toward dorsal surface, not reaching black sutural area; large, elongate black macula starting centrally, ending about posterior quarter, distinctly reaching dorsal surface, not reaching black sutural area, with its anterior region fused with black epipleural margin, then gradually separated from epipleural margins toward its narrowed apex (this macula gradually brownish toward its apex); posterior seventh mostly brownish. Pro- and mesocoxae black basally, orange on remaining surface; metacoxae mostly orange, with some areas slightly brownish. Profemora orange except black posterior $2 / 3$ of dorsal surface and superior area of sides; mesofemora orange except black posterior half of dorsal surface, and entire apex (black posterior area gradually narrowed laterally); metafemora orange on basal half, black on posterior half. Tibiae and tarsi black. Abdominal ventrite I orange except narrow, transverse brownish band close to posterior margin; II black, except orange centrally; III black basally (this area distinctly widened laterally), orange on remaining surface; IV mostly orangish brown, with on brown macula on each side of anterior region, and brown apex; $\mathrm{V}$ orangish brown centrally (this area slightly darker than on IV), brown laterally.

HEAD. Frons somewhat elevated along median groove, this area drop-shaped with its widest area toward clypeus, depressed inside, its sides as a carinate projection of antennal tubercles, smooth except a few fine punctures on its widest area; sides and central area close to clypeus finely, abundantly punctate; with short, erect, moderately abundantly yellowish-brown setae on punctate area, with a few long, erect setae of same color interspersed, glabrous on elevated central area; frontoclypeal suture absent. Vertex finely, densely, partially confluently punctate before constricted neck, punctures finer and denser than on frons; neck finely, abundantly punctate, punctures coarser than on anterior region of vertex, not confluent, slightly sparser centrally; area before neck with short, abundant yellowish-brown setae, and a few long, erect setae of same color interspersed; neck with yellowish-brown setae shorter, distinctly sparser than on anterior region of vertex, especially centrally. Tumid area behind upper eye lobes smooth close to vertex, finely, sparsely punctate close to lower eye lobe; neck area finely, sparsely punctate (punctures coarser than on vertex); with abundant erect setae close to vertex, with short, sparse yellowish-brown setae on remaining surface. Tumid area behind lower eye lobes obliquely striate-punctate; neck area longitudinally striate-punctate; with short, sparse yellowish-brown setae, longer, slightly more abundant on tumid area close to inferior margin. Genae about as long as maximum width of lower eye lobe; carinate close to frons and clypeus, longitudinally depressed close to carina; finely, abundantly punctate on depressed area, finely, sparsely punctate on remaining surface; with short, sparse yellowish-brown setae, slightly longer and more abundant close to carina. Clypeus finely, moderately sparsely punctate close to frons, smooth close to labrum; with short, erect, moderately sparse yellowish-brown setae on punctate area, longer laterally, glabrous on smooth area. Labrum with short, sparse golden setae centrally, longer, abundant laterally, and fringe of golden setae on anterior margin. Maxillary palpomeres IV not widened apically, general shape nearly fusiform. Gulamentum somewhat rugose-punctate, with short, erect, moderately abundant yellowish-brown setae, and a few long setae of same color interspersed. Distance between upper eye lobes 0.95 times length of scape, 0.49 times distance between outer margins of eyes; in frontal view, distance between lower eye lobes 0.83 times length of scape, 0.42 times distance between outer margins of eyes. Antennae 1.35 times elytral length, surpassing middle of elytra; with yellowish-brown pubescence not obscuring integument, appearing to be darker due to integument color, 
especially depending on angle of light source; antennomeres III-IV cylindrical, antennomere V slightly widened toward apex; antennomeres VI-X subserrate; antennomere XI cylindrical in basal $2 / 3$, acutely narrowed toward apex in posterior third; sensory depressions on antennomeres VIII-XI eroding apex of segment. Antennal formula (ratio) based on length of antennomere III: scape $=0.68$; pedicel $=0.11$; IV $=$ $0.82 ; \mathrm{V}=1.00 ; \mathrm{VI}=0.86 ; \mathrm{VII}=0.79 ; \mathrm{VIII}=0.68 ; \mathrm{IX}=0.65 ; \mathrm{X}=0.57 ; \mathrm{XI}=0.79$.

Thorax. Prothorax slightly longer than wide, with anterior constriction well-marked; sides gradually widened from rounded anterolateral angles to acute posterolateral angles, rounded, widened before middle. Pronotum with anterior margin straight, and posterior margin rounded, widely projected centrally; surface finely, densely punctate, except smooth central area near anterior margin, and central longitudinal sulcus from apex of anterior quarter to base of posterior quarter; with abundant golden pubescence close
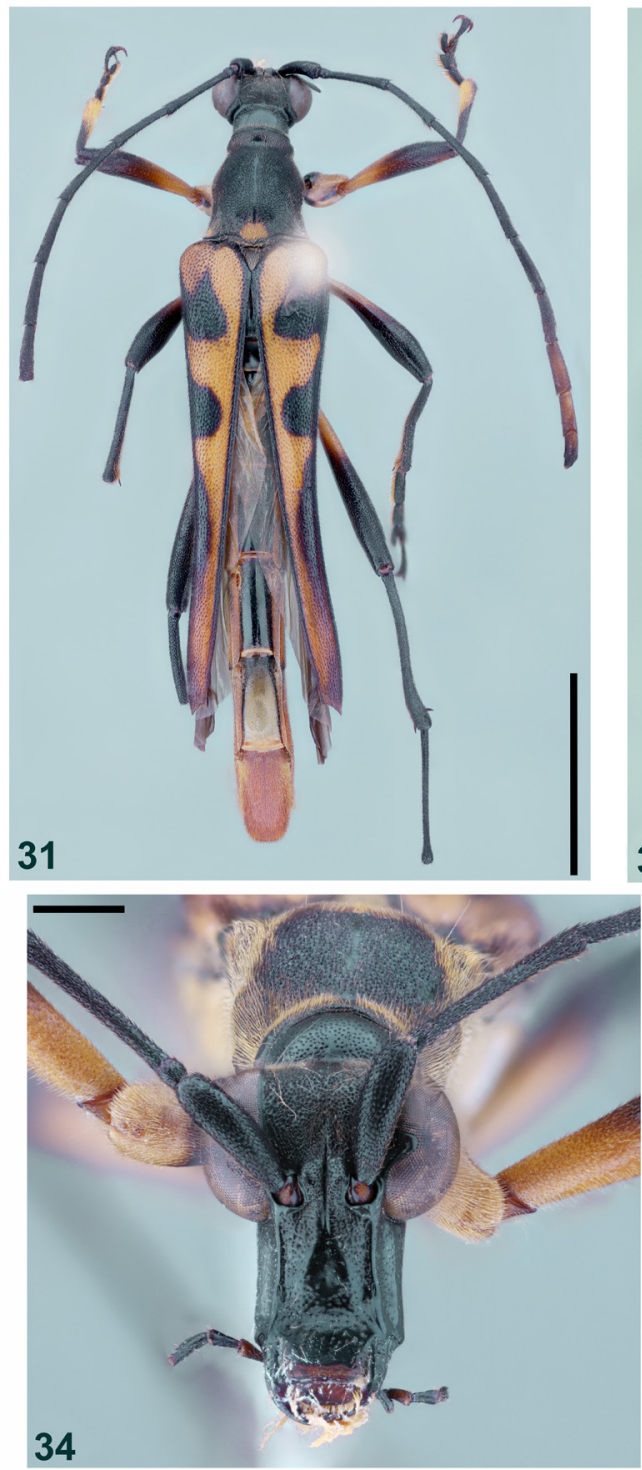
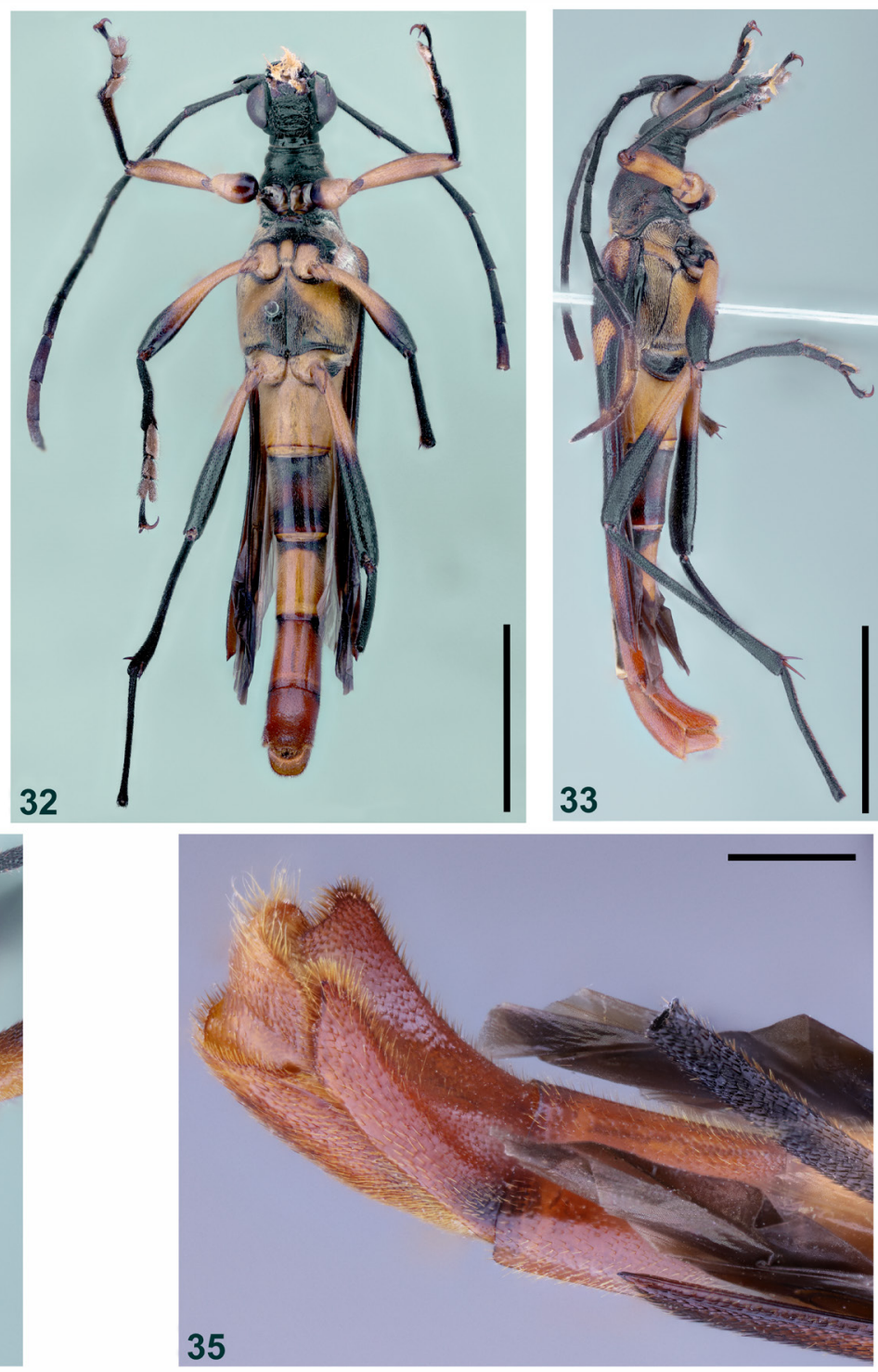

Figs 31-35. Strangalia lunai sp. nov., holotype, $\widehat{O}$ (RBINS 34.248). 31. Habitus, dorsal view. 32. Habitus, ventral view. 33. Habitus, lateral view. 34. Head, frontal view. 35. Apex of abdomen. Scale bars $=1.0 \mathrm{~mm}$. 
to anterior margin (pubescence absent on smooth area), sides, and on posterocentral orange macula; remaining surface with yellowish-brown pubescence distinctly not obscuring integument. Sides of prothorax finely, densely punctate, except nearly smooth anterior area, and coarse, shallow, sparse punctures interspersed on posterior half; with abundant golden pubescence not obscuring integument, except nearly glabrous anterior area (with a few long, erect setae close to prosternum on this latter area). Prosternum finely, densely punctate on sides of posterior half, punctures sparse centrally, mostly smooth centrally, somewhat rugose-punctate laterally on anterior half; sides with abundant, short, bristly golden setae, distinctly sparer centrally. Prosternal process laminiform on wide central area. Mesoventrite finely, densely punctate except smooth lateral apices; with golden pubescence not obscuring integument, except glabrous smooth areas. Mesoventral process somewhat tumid centrally; with abundant golden pubescence on posterior half. Mesanepisternum and mesepimeron with abundant yellowish pubescence. Metanepisternum and metaventrite with abundant golden pubescence; metaventrite lacking tubercles or carina centrally near apex. Scutellum with abundant golden pubescence.

ELYTRA. Distinctly narrowed from humerus to about middle, then with outer and sutural margins nearly parallel sided toward oblique apex; outer apical angle spiniform; sutural angle with short spiniform projection; moderately coarsely, abundantly punctate throughout; orange area with golden pubescence not obscuring integument, except area closer to dark integument with decumbent, moderately abundant black setae; black area with grayish pubescence not obscuring integument, appearing to be darker depending on angle of light source, especially due to integument color. Femora with yellowish pubescence not obscuring integument, appearing to be darker on black area due to integument color and angle source. Tibiae with golden pubescence, denser posteriorly, especially ventrally; metatibia with tubercle or plate apically.

AвDOMEN. Surpassing elytral apex about middle of forth segment. Ventrites with abundant yellowish pubescence not obscuring integument; ventrite $\mathrm{V}$ excavated for less than $3 / 4$ its length, with sides not strongly flap-shaped.

\section{Remarks}

Strangalia lunai sp. nov. can be included in the alternative of couplet '26' from Giesbert (1997):

26(25). Pronotum about as long as width across base; disk with narrow, longitudinal, median, glabrous

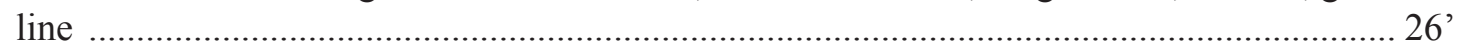

- $\quad$ Pronotum shorter than width across base; disk without glabrous line ................................... 27

26'(26). Antennae nearly reaching elytral apex; outer elytral margin entirely black; sides of abdominal ventrite $\mathrm{V}$ flap-shaped from base to apex. Guatemala S. zacapensis Giesbert, 1997

- $\quad$ Antennae distinctly not reaching elytral apex; outer elytral margin not entirely black; sides of abdominal ventrite V not flap-shaped from base to apex. Honduras S. lunai sp. nov.

\section{Discussion}

By noting the unavailability of the name Cerambyx ypsilon Voet, we have eliminated only one of the names currently in use in Cerambycidae attributed to Johannes Eusebius Voet. We know that in some cases there are names in synonymy which need to be used as valid. However, in a few cases, there are no names in synonymy. This creates a curious situation since, formally, these species cannot be considered as described. Therefore, it will be necessary to study each of the names assigned to that author and apply the appropriate solution.

Our results increase the number of known species of Compsina from Honduras to 26; Acrocinini to eight; Apomecynini to 34; and Lepturini to 14 . The constant and ongoing discovery of new species of 
Cerambycidae illustrates the current incomplete taxonomic overview of this family and suggests that a large number of species remains to be discovered. Unfortunately, the number of longhorn taxonomists worldwide has declined dramatically in recent decades, slowing down the study of this taxon. This is particularly worrisome considering the rapidly accelerating habitat loss such as deforestation in Honduras and globally. Probably many longhorn species and other animals and plants go extinct and disappear before being officially recognized and recorded. A drastic surge in effort is needed to conserve the remaining species, habitats and biodiversity.

\section{Acknowledgments}

Thank you to the people from Buenos Aires and Tierra Santa for guidance in the forest. We thank Operation Wallacea Ltd staff and students for sample collection in the field, especially Ruben Elsen, Tom Martin, Declan Crace, Frederik De Wint, Tom Brown, Lore Geeraert, Sam Jones, and Siel Wellens. We acknowledge the Instituto de Conservación Forestal (ICF, Tegucigalpa, Honduras), who provided permits to work within CNP, and Roberto Downing from Expediciones y Servicios Ambientales de Cusuco (ESAC) for support on permits and logistics. We thank Wouter Dekoninck and Alain Drumont (RBINS) for their support and expertise. Thanks are also due to Michelle D'Souza for facilitating the longhorn loan from CBG (Canada). We thank Eugenio Nearns (USNM) and Jan Mertens (BINCO) for their valuable feedback prior to submission. Lastly, we would like to thank the editor of EJT and two anonymous reviewers for their time and feedback, as such improving this manuscript.

\section{References}

Alonso-Zarazaga M.A. \& Lyal C.H.C. 1999. A World Catalogue of Families and Genera of Curculionoidea (Insecta: Coleoptera). (Excepting Scolytidae and Platypodidae). Entomopraxis, Barcelona.

Anderson R.S. \& Ashe J.S. 2000. Leaf litter inhabiting beetles as surrogates for establishing priorities for conservation of selected tropical montane cloud forests in Honduras, Central America (Coleoptera; Staphylinidae, Curculionidae). Biodiversity \& Conservation 9: 617-653.

https://doi.org/10.1023/A:1008937017058

Aurivillius C. 1922. Cerambycidae: Lamiinae I. In: Schenkling S. (ed.) Coleopterorum Catalogus auspiciis et auxilio W. Junk, pars 73, Cerambycidae: Lamiinae: 1-322. W. Junk, Berlin. Available from https://www.biodiversitylibrary.org/page/10202648 [accessed 23 Jul. 2021].

Aurivillius C. 1923. Cerambycidae: Lamiinae II. In: Schenkling S. (ed.) Coleopterorum Catalogus auspiciis et auxilio W. Junk, pars 74, Cerambycidae: Lamiinae: 323-704. W. Junk, Berlin. Available from https://www.biodiversitylibrary.org/page/10202648 [accessed 23 Jul. 2021].

Bates H.W. 1881a. Longicornia. In: Godman F.D. \& Salvin O. (eds) Biologia Centrali-Americana Insecta, Coleoptera Vol. 5: 153-224. Taylor \& Francis, London. https://doi.org/10.5962/bhl.title.730

Bates H.W. 1881b. Notes on longicorn Coleoptera. Revision of the aerénicides and amphionychides of tropical America. The Annals and Magazine of Natural History Series 5 8: 290-306.

https://doi.org/10.1080/00222938109487459

Beckmann J. 1776. XV. Catalogue raisonné ou systématique du genre des insectes, qu'on appelle Coléoptères, par Jean Eusèbe Voet. In: Beckmann J. (ed.) Physikalisch-ökonomische Bibliothek: worinn von den neuesten Büchern, welche die Naturgeschichte, Naturlehre und die Land-und Stadtwirthschaft betreffen, zuverlässige und vollständige Nachrichten ertheilet werden. Siebenter Band: 104-108. Wittwe Vandenhoeck, Göttingen.

Bezark L.G. 2021a. Checklist of the Oxypeltidae, Vesperidae, Disteniidae and Cerambycidae (Coleoptera) of the Western Hemisphere. 2021 Edition (updated through 31 December 2020). Available from http://bezbycids.com/byciddb/wdefault.asp?w=n [accessed 2 Aug. 2021]. 
Bezark L.G. 2021b. A Photographic Catalog of the Cerambycidae of the World. New World Cerambycidae Catalog. Available from http://bezbycids.com/byciddb/wdefault.asp?w=n [accessed 2 Aug. 2021].

Blackwelder R.E. 1946. Checklist of the coleopterous insects of Mexico, Central America, the West Indies and South America. Part 4. Bulletin of the United States National Museum 185: 551-763. https://doi.org/10.5479/si.03629236.185.4

British Museum (Natural History) 1915. Catalogue of the Library of the British Museum (Natural History) Vol. 5: 1957-2403. British Museum (Natural History), London.

Bruijnzeel L.A. \& Veneklaas E. 1998. Climatic conditions and tropical montane forest productivity: the fog has not lifted yet. Ecology 78: 3-9.

https://doi.org/10.1890/0012-9658(1998)079[0003:ccatmf]2.0.co;2

Casey T.L. 1913. Further studies among the American Longicornia. Memoirs on the Coleoptera 4: 193388. Available from https://www.biodiversitylibrary.org/page/963015 [accessed 23 Jul. 2021].

Chemsak J.A. \& Linsley E.G. 1970. Additional designations of lectotypes of Neotropical Cerambycidae in the collections of the British Museum (Natural History) (Coleoptera). Journal of the Kansas Entomological Society 43 (4): 404-417.

Chemsak J.A., Linsley E.G. \& Noguera F.A. 1992. Listados Faunísticos de México. II. Los Cerambycidae y Disteniidae de Norteamérica, Centroamérica y las Indias Occidentales (Coleoptera). Universidad Nacional Autónoma, Mexico City.

Dejean P.F.M.A. 1835. Catalogue des Coléopteres de la collection de M. le Comte Dejean [Livraison 4]: 257-360. Méquignon-Marvis, Paris. https://doi.org/10.5962/bhl.title.8771

Dillon L.S. 1956. The Nearctic components of the tribe Acanthocinini (Coleoptera, Cerambycidae). Part I. Annals of the Entomological Society of America 49 (2): 134-167. https://doi.org/10.1093/aesa/49.2.134

Dillon L.S. 1957. Revision of the Neotropical Acanthocinini (Coleoptera: Cerambycidae). II. The genus Lagocheirus. Bulletin of the British Museum of Natural History (Entomology) 6: 137-166. https://doi.org/10.5962/bhl.part.17106

Dryander J. \& Banks J. 1796. Catalogus Bibliothecae Historico-naturalis Josephi Banks Vol. 2. Zoologi. Gul. Bulmer et Soc., London. https://doi.org/10.5962/bhl.title.124897

D'Souza M.L. \& Hebert P. 2018. Stable baselines of temporal turnover underlie high beta diversity in tropical arthropod communities. Molecular Ecology 27 (10): 2447-2460.

https://doi.org/10.1111/mec.14693

Erichson W.F. 1847. Conspectus Insectorum Coleopterorum quae in Republica Peruana observata sunt. Archiv für Naturgeschichte 13: 67-185. Available from https://www.biodiversitylibrary.org/page/7251438 [accessed 23 Jul. 2021].

Galileo M.H.M. \& Martins U.R. 2005. Contribuição aos Hemilophini da Costa Rica (Coleoptera, Cerambycidae, Lamiinae). Papéis Avulsos de Zoologia 45 (10): 103-109.

https://doi.org/10.1590/S0031-10492005001000001

Giesbert E.F. 1997. Further studies in the Lepturini (Coleoptera, Cerambycidae, Lepturinae) of Central America. Occasional Papers of the Consortium Coleopterorum 1 (1): 17-42.

Gilmour E.F. 1965. Catalogue des Lamiaires du Monde (Col., Cerambycidae). 8 Lieferung: 559-655. Museum G. Frey, Tutzing bei München.

Global Witness. (2017, January 31). Honduras: the deadliest country in the world for environmental activism. Available from https://www.globalwitness.org/ [accessed 11 Jan. 2020]. 
Gutiérrez N., Toledo-Hernández V.H. \& Noguera F.A. 2020. Four new species of Phrynidius Lacordaire (Coleoptera, Cerambycidae, Lamiinae) from Mexico with an identification key for the genus. ZooKeys 1000: 45-57. https://doi.org/10.3897/zookeys.1000.56757

Hansen M.C., Wang L., Song X., Tyukavina A., Turubanov S., Potapov P.V. \& Stehman S.V. 2020. The fate of tropical forest fragments. Science Advances 6 (11): eaax8574.

https://doi.org/10.1126/sciadv.aax8574

Hovore F.T. 2006. The Cerambycidae (Coleoptera) of Guatemala. In: Cano E. (ed.) Biodiversidad de Guatemala. Vol. 1: 363-378. Universidad del Valle de Guatemala, Guatemala City.

Jones R.W., O’Brien C.W., Ruiz-Montoya L. \& Gómez-Gómez B. 2008. Insect diversity of tropical montane forests: diversity and spatial distribution of weevils (Coleoptera: Curculionidae) inhabiting leaf litter in southern Mexico. Annals of the Entomological Society of America 101: 128-139.

https://doi.org/10.1603/0013-8746(2008)101[128:IDOTMF]2.0.CO;2

Krell F.T. 2012. On nomenclature and synonymy of Trichius rosaceus, T. gallicus, and T. zonatus (Coleoptera: Scarabaeidae: Cetoniinae: Trichiini). Zootaxa 3278 (1): 61-68.

https://doi.org/10.11646/zootaxa.3278.1.3

Lameere A.A. 1883. Liste des cérambycides, décrits postérieurement au catalogue de Munich. Annales de la Société entomologique de Belgique 26: 1-78.

Le Saout S., Hoffmann M., Shi Y., Hughes A., Bernard C., Brooks T.M., Bertzky B., Butchart S.H.M., Stuart S.N., Badman T. \& Rodrigues A.S.L. 2013. Protected areas and effective biodiversity conservation. Science 15: 803-805. https://doi.org/10.1126/science.1239268

Linsley E.G. \& Chemsak J.A. 1995. The Cerambycidae of North America. Part VII, No. 2. Taxonomy and classification of the subfamily Lamiinae, tribes Acanthocinini through Hemilophini. University of California, Publications in Entomology 114: i-xii + 1-292.

Magrin G.O., Marengo J.A., Boulanger J.-P., Buckeridge M.S., Castellanos E., Poveda G., Scarano F.R. \& Vicuña S. 2014. Central and South America. In: Barros V.R., Field C.B., Dokken D.J., Mastrandrea M.D., Mach K.J., Bilir T.E., Chatterjee M., Ebi K.L., Estrada Y.O., Genova R.C., Girma B., Kissel E.S., Levy A.N., MacCracken S., Mastrandrea P.R. \& White L.L. (eds) Climate Change 2014: Impacts, Adaptation, and Vulnerability. Part B: Regional Aspects. Contribution of Working Group II to the Fifth Assessment Report of the Intergovernmental Panel on Climate Change: 1499-1566. Cambridge University Press, Cambridge. https://doi.org/10.1017/CBO9781107415386.007

Martin T.E., Jones S.E.I., Creedy T.J., Hoskins H.M.J., McCann N.P., Batke S.P., Kelly D.L., Kolby J.E., Downing, R., Zelaya S.M.S., Green S.E.W., Lonsdale G., Brown T., Waters S., Rodriguez F., McCravy K.W., Souza M.L.D, Crace D. Nunez-Mino J.M., Haelewaters D., Medina-Van Berkum P., Phipps C.D., Barker R.J., Castaneda F., Reid N. \& Jocqué M. 2021. A review of the ecological value of Cusuco National Park: an urgent call for conservation action in a highly threatened Mesoamerican cloud forest. Journal of Mesoamerican Biology 1 (1): 6-50.

Martins U.R. \& Galileo M.H.M. 1992. Gêneros de Hemilophini (Coleoptera, Cerambycidae, Lamiinae) relacionados com Hemilophus A.-Serville, 1835. Revista Brasileira de Entomologia 36 (1): 121-128.

McCarty J.D. 2001. A review of the Mexican species of Oreodera Audinet-Serville (Coleoptera, Cerambycidae). Occasional Papers of the Consortium Coleopterorum 4 (1): 13-34.

Monné M.A. 1995. Catalogue of the Cerambycidae (Coleoptera) of the Western Hemisphere. Part XX. Subfamily Lamiinae: Tribos Hemilophini, Aerenicini, Pretiliini, Falsamblesthiini and Calliini. Sociedade Brasileira de Entomologia, São Paulo. 
Monné M.A. 2005. Catalogue of the Cerambycidae (Coleoptera) of the Neotropical Region. Part II. Subfamily Lamiinae. Zootaxa 1023 (1): 1-759. https://doi.org/10.11646/zootaxa.1023.1.1

Monné M.A. 2021. Catalogue of the Cerambycidae (Coleoptera) of the Neotropical region. Part II. Subfamily Lamiinae. Available from

https://cerambycids.com/default.asp?action=show_catalog [accessed 2 Aug. 2021].

Monné M.A. \& Giesbert E.F. 1994. Checklist of the Cerambycidae and Disteniidae (Coleoptera) of the Western Hemisphere. Wolfsgarden Books, Burbank.

Monné M.A. \& Hovore F.T. 2006. A Checklist of the Cerambycidae, or Longhorned Wood-Boring Beetles, of the Western Hemisphere. Bio Quip Publications, Rancho Dominguez.

Myers N., Mittermeier R.A., Mittermeier C.G., da Fonseca G.A.B. \& Kent J. 2000. Biodiversity hotspots for conservation priorities. Nature 403: 853-858. https://doi.org/10.1038/35002501

Noguera F.A. \& Chemsak J.A. 1996. Cerambycidae (Coleoptera). In: Llorente Bousquets J.E., García Aldrete A.N. \& González Soriano E. (eds) Biodiversidad, Taxonomía y Biogeografia de Artrópodos de México: Hacia una Síntesis de su Sonocimiento Vol. I: 381-409. Universidad Nacional Autónoma de México, Mexico City.

Pope I., Bowen D., Harbor J., Shao G., Zanotti L. \& Burniske G. 2015. Deforestation of montane cloud forest in the Central Highlands of Guatemala: contributing factors and implications for sustainability in Q'eqchi' communities. International Journal of Sustainable Development \& World Ecology 22 (3): 201-212. https://doi.org/10.1080/13504509.2014.998738

Santos-Silva A., Martins U.R. \& Tavakilian G.L. 2010. Revisão do gênero Polyrhaphis Audinet-Serville (Coleoptera, Cerambycidae, Lamiinae). Papéis Avulsos de Zoologia 50 (30): 451-509.

https://doi.org/10.1590/S0031-10492010003000001

Santos-Silva A., Mal N., Van Roie M. \& Jocqué M. 2018. A new species of Derobrachus AudinetServille, 1832 (Coleoptera, Cerambycidae, Prioninae) from a cloud forest in Honduras. Zootaxa 4422 (3): 395-402. https://doi.org/10.11646/zootaxa.4422.3.5

Schönherr C.J. 1817. Synonymia Insectorum, oder: Versuch einer Synonymia aller bisher bekannten Insecten; nach Fabricii Systema Eleutheratorum \&c. geordnet Band 1, Theil 3. E. Bruzelius, Uppsala. https://doi.org/10.5962/bhl.title.66107

Sherborn C.D. 1902. Index Animalium sive index nominum quae ab a.d. MDCCLVIII generibus et speciebus animalium imposita sunt. Sectio Prima: a kalendis ianuariis, MDCCLVIII usque ad finem decembris, MDCCC. E Typographio Academico, Cambridge. Available from

https://www.sil.si.edu/DigitalCollections/indexanimalium/TaxonomicNames/ [accessed 23 Jul. 2021].

Swift I.P., Bezark L.G., Nearns E.H., Solís A. \& Hovore F.T. 2010. Checklist of the Cerambycidae (Coleoptera) of Costa Rica. Insecta Mundi 0131: 1-68.

Voet J.E. [1766-]1806. Catalogus Systematicus Coleopterorum - Catalogue Systematique des Coleopteres - Systematische Naamlyst van dat geslacht van Insecten dat men Torren noemt Vol. 2. G. Bakhuysen, La Haye. Note: Work added to new parts at each reissue. Each part (Latin, French, and Dutch) has an independent pagination. https://doi.org/10.5962/bhl.title.5051

Manuscript received: 8 January 2021

Manuscript accepted: 21 June 2021

Published on: 23 August 2021

Topic editor: Nesrine Akkari 
Section editor: Max Barclay

Desk editor: Pepe Fernández

Printed versions of all papers are also deposited in the libraries of the institutes that are members of the EJT consortium: Muséum national d'histoire naturelle, Paris, France; Meise Botanic Garden, Belgium; Royal Museum for Central Africa, Tervuren, Belgium; Royal Belgian Institute of Natural Sciences, Brussels, Belgium; Natural History Museum of Denmark, Copenhagen, Denmark; Naturalis Biodiversity Center, Leiden, the Netherlands; Museo Nacional de Ciencias Naturales-CSIC, Madrid, Spain; Real Jardín Botánico de Madrid CSIC, Spain; Zoological Research Museum Alexander Koenig, Bonn, Germany; National Museum, Prague, Czech Republic. 